\title{
Studies on the effects of Zingiber officinale Roscoe (Ginger) aqueous and ethanolic extracts on some fungal and bacterial species
}

\author{
Ogbonna, A.I. ${ }^{* 1}$, Tanko, J.S. ${ }^{2}$, Falemara, B.C. ${ }^{2}$, Itelima, J.U. ${ }^{1}$, Makut, M.D. ${ }^{1}$, \\ Onyimba, I. ${ }^{1}$ and Chuku, A. ${ }^{3}$ \\ ${ }^{1}$ Faculty of Natural Sciences, University of Jos, Nigeria. \\ ${ }^{2}$ Federal College of Forestry, Jos, Nigeria. \\ ${ }^{3}$ Department of Microbiology, Federal University, Lafia, Nasarawa State.
}

\begin{abstract}
The effects of aqueous and ethanolic extracts of Zingiber officinale (ginger) on some species of fungi isolated from soil samples collected from two barbers' landfills and some clinical bacterial isolates were studied. The test isolates included Aspergillus flavus, Curvularia lunata, Fusarium solani, Penicillium species, Bacillus species, Citrobacter species and Staphylococcus aureus. The concentrations of the extracts used included $500 \mathrm{mg} / \mathrm{ml}, 250 \mathrm{mg} / \mathrm{ml}, 125 \mathrm{mg} / \mathrm{ml}, 62.5 \mathrm{mg} / \mathrm{ml}$ and $31.25 \mathrm{mg} / \mathrm{ml}$. The aqueous extract of Z. officinale proved to be more antimicrobial on the test organisms than the ethanolic extract with an inhibitory zone diameter of $46 \mathrm{~mm}$ at a concentration of $500 \mathrm{mg} / \mathrm{ml}$. As for the clinical bacteria, S. aureus was the most inhibited, with an inhibitory zone diameter of $35 \mathrm{~mm}$ by the same aqueous extract at $500 \mathrm{mg} / \mathrm{ml}$ concentration. The effects of the said aqueous extract of the plant compared favourably with the effects observed from the standard drugs, nystatin $5 \mu \mathrm{g} / \mathrm{ml}$ and gentamycin $40 \mathrm{mg} / \mathrm{ml}$ on the test fungi and bacteria respectively. The implications of the results obtained have been discussed.
\end{abstract}

Keywords: Fungal isolates, barbers' landfills, clinical bacteria, Zingiber officinale extracts, inhibition.

\section{Introduction}

The soil is rich in pathogenic and non pathogenic keratinophilic fungi including dermatophytes. Most fungal isolates have been reported as dermatophytes causing infections of skin, scalp, hair, nails $(1,2)$. These groups of fungi are involved in the degradation of most abundant and highly stable animal protein-keratin, which they utilize as sole sources of carbon and nitrogen (3). The potentially pathogenic and non-pathogenic fungal species are present in the environment with variable distribution patterns that depend on different factors such as human and or animal presence and also occur both in soils and wastewater habitats, forests, farmyards, park soils, as well as sediments of rivers and oceans containing humus and organic material $(4,5)$.

In the recent years, many workers have reported the distribution of pathogenic fungi and related dermatophytes in soils especially parks and zoos $(6,7,8)$.

In Nigeria, incidence of dermatophyte infections among groups from different works of life including school children. Ogbonna et al. (9) in their survey on the distribution of ringworm infections among primary school children in Jos, Plateau State of Nigeria reported a high incidence of both scalp and foot ringworms among the infected children. Other surveys conducted in Jos, Nigeria have demonstrated the occurrence of a variety of pathogenic fungi and related dermatophytes on nomadic Fulani herdsmen (10), agro-farm workers, Jos prison inmates, hair weavers and car washers (11). Dermatophytes and nonDermatophytes can colonize and invade the keratin of skin, nails and hair (12). Apart of fungi, keratin utilization has also been reported in other organisms (13). The occurrence of Dermatophytes and other keratinophilic fungi enhances the risk of human Dermatophytosis in those regions, which could have a role in degradation of keratinous material. Barbers' landfill has been observed as one of those regions that have accumulation of keratinous materials which is made up of mainly human hairs. In the recent years, many works have reported on the distribution of dermatophytes and non-dermatophytes in soils (2). So far no much work has been carried out from soil samples collected from barbers' landfills.

The rhizome of Zingiber officinale is one of the most widely used species of the ginger family (Zingiberaceae) and is a common condiment for various foods and beverages. It has been used for thousands of centuries to enhance the flavor and aroma of food. It has been confirmed to have antimicrobial properties and it shares its pharmacological properties with non-steroidal anti-inflammatory drugs (14). Ginger is a strong antioxidant substance and may either mitigate or prevent generation of free radicals. This natural herbal product is known to have powerful antifungal properties. In the present study, attempt was made to evaluate the effect of aqueous and ethanolic extracts of Zingiber officinale (ginger) on some of pathogenic fungal isolates from soils collected from barbers' landfill and some pathogenic clinical isolates including bacteria. 


\section{Materials And Methods}

Collection and Processing of Soil Samples

Soil samples were collected from three (3) locations of 10 different barbers' landfills. A total of 30 soil samples were collected from the 10 sites at three points each. Soil samples were collected from $5 \mathrm{~cm}$ depth in sterile, tightly closed polythene bags using clean hand shovel. The samples were stored at $4^{\circ} \mathrm{C}$ and were processed within two days of collection. The hair-baiting technique of (15) was employed for selective isolation of keratinophilic fungi. A weight $50 \mathrm{~g}$ of each sample was transferred to a sterile Petri plate, and pieces of sterilized and defatted hair were spread over the soil in the plate. The hair-baited soils in the plates were moistened with sterile distilled water. The Petri dishes were labeled properly, wrapped with foil paper and were incubated at $\left(25 \pm 2^{\circ} \mathrm{C}\right)$ for eight weeks. The soil samples were moistened periodically with small quantities of sterile distilled water. After the growth of fungi on the baited hair (Fig 1), the colonized hair strands were inoculated on Sabouraud Dextrose Agar (SDA) medium supplemented with chloramphenicol $50 \mathrm{mg} \mathrm{L}^{-1}$ and streptomycin sulphate $100 \mathrm{mg} \mathrm{L}^{-1}$ to suppress the growth of bacteria. The Petri dishes were incubated for 3 weeks at $28 \pm 2^{\circ} \mathrm{C}$. The colonies that developed were sub-cultured severally until pure cultures were obtained.

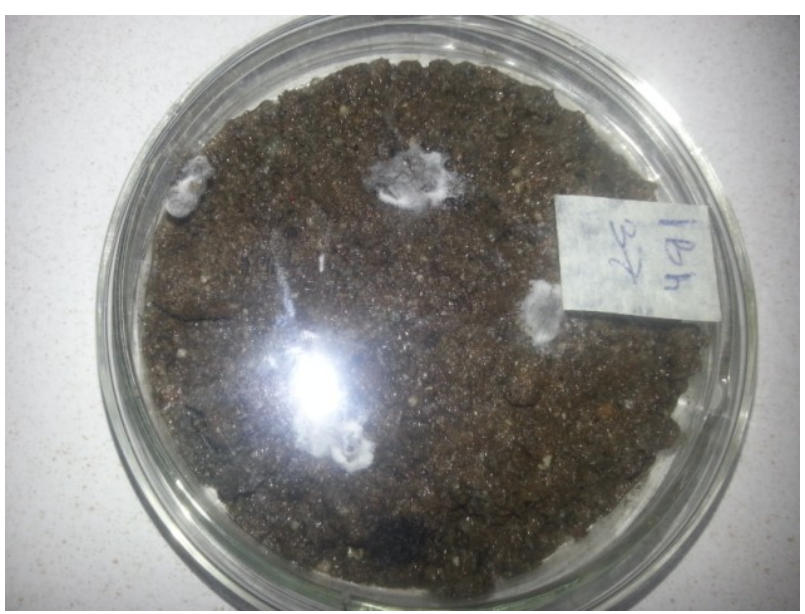

Plate 1: Growth of fungi on "Baited Hairs"

\subsection{Identification of Fungal Isolates}

\subsubsection{Morphological Identification}

The microscopic studies were done on the basis of morphological characteristics. Tape method was adopted for the identification of fungal isolates with lactophenol cotton blue. References were also made to Domsh and Gams (16), Von Arx (17), Barron (18), Raper and Fennel (19), Samson et. al., (20) and De Hoog et al., (21).

\subsubsection{Biochemical Identification}

All the fungal colonies were examined for amylase production, casein hydrolysis and protease activity. Urease hydrolysis and In vitro Hair test were also conducted for Trichophyton mentagrophytes which was the only dermatophyte isolated from the study.

\subsection{Thermotolerance Studies}

Thermotolerance studies were carried out on the fungal isolates by incubating them at $25^{\circ} \mathrm{C}, 37^{\circ} \mathrm{C}, 40^{\circ} \mathrm{C}$ and $45^{\circ} \mathrm{C}$ on SDA medium. The medium was supplemented with chloramphenicol $50 \mathrm{mg} \mathrm{L}^{-1}$ and streptomycin sulphate $100 \mathrm{mg} \mathrm{L}^{-1}$ to inhibit bacterial growth. The Petri plates were incubated at the various temperature regimes for five (5) days and the results were recorded. This experiment was done in triplicates.

\subsection{Antimicrobial Studies}

\subsubsection{Preparation of plant material}

Samples of the bulbs of Zingiber officinale (ginger) were bought from terminus market here in Jos. The plant was identified in the herbarium of College of Forestry Jos were a voucher specimen was deposited. Using modified method of (22), the bulbs were sliced and dried at $50^{\circ} \mathrm{C}$ for 5 days using oven. After drying, the samples were pulverized using mortar and pestle. 


\subsubsection{Extraction of plant material}

For the aqueous extract of the plant material, a weight of $100 \mathrm{~g}$ was measured into a $500 \mathrm{ml}$ beaker and was extracted using $300 \mathrm{ml}$ of sterile distilled water. The same experiment was repeated for the ethanolic extract using $300 \mathrm{ml}$ of $96 \%$ ethanol. They were extracted under cold conditions for $24 \mathrm{~h}$. The resultant extracts were filtered through Whatman No. 1 filter paper and then rinsed with $30 \mathrm{ml}$ of sterile distilled water and $96 \%$ ethanol respectively. The extracts solutions were evaporated under reduced pressure at $50^{\circ} \mathrm{C}$.

\subsubsection{Test Organisms}

Pathogenic test fungi used for the antimicrobial study were selected from fungal isolates obtained from the soils from the barbers' landfills. They included Aspergillus flavus, Curvularia lunata, Fusarium solani, Penicillium sp and one yeast, Candida albicans. The test bacteria were collected from the University of Jos Health Centre and included Bacillus sp, Citrobacter sp and Staphylococcus aureus.

\subsubsection{Preparation of Inoculums}

Potato Dextrose broth and Nutrient broth prepared aseptically and dispensed in McCartney bottles were inoculated with Candida albicans and all the test bacteria respectively. The bottles were labelled and then incubated for $24 \mathrm{~h}$ at $37^{\circ} \mathrm{C}$. For the other test fungi, their spore suspensions were obtained. The microbial suspensions were adjusted to have $10^{6}$ cells $/ \mathrm{ml}$ before use.

\subsubsection{Antimicrobial sensitivity screening}

The antimicrobial activity of both the aqueous and ethanolic extracts was determined using the agar well diffusion method described by Tortora et al. (23). The culture suspension of test fungi and yeast were spread on SDA plates while that of bacteria was spread on Muller Hinton agar (MH, E. Merk, Germany) and allowed to dry for 5 mins. Holes were bored on the agar plates using $6 \mathrm{~mm}$ sterile cork borer. A volume of $0.2 \mathrm{ml}$ of the different concentrations of the aqueous extract was introduced into the wells; this was repeated for the ethanolic extract. Nystatin and Gentamycin were used as control for fungi and bacteria respectively. The plates were done in triplicates and were incubated at $37^{\circ} \mathrm{C}$ for yeast and bacteria and $25^{\circ} \mathrm{C}$ for fungi. The antimicrobial activity was taken on the basis of diameter of inhibition zones (DIZ) in $\mathrm{mm}$, which was measured after $24 \mathrm{~h}$ of incubation for yeast and bacteria and 7 days for fungi and the means of three readings recorded.

\subsection{Species of Fungi Isolated From the Experimental Soil Sample \\ III. Results and Discussion}

A total of 15 isolates were obtained from the analyses of 30 samples taken from soils of three different barber's landfills. Fourteen of the isolates belong to 10 genera of filamentous fungi and 1yeast species belonging to genera Candida. The soil samples yielded only one species of dermatophyte, Trichophyton mentagrophytes and one species of pathogenic yeast isolate, Candida albicans representing $6.67 \%$ each of the total isolates. The other non-dermatophyte keratinophylic fungi dominated the soil and represents $86.67 \%$ of the total isolates. Aspergillus niger and Trichoderma viride were the most frequently isolated species (100\%), followed by $A$. fumigatus and Penicillium sp (8.89\%), A. flavus, A. terreus and Curvularia lunata (7.78\%), A. niveus and Basidiobolus sp (6.67\%), Trichophyton mentagrophytes, Cladosporium cladosporioides and Emericella nidulans (5.56\%), Fusarium solani and Candida albicans (3.33\%). The least was Cunninghamella elegans with $2.22 \%$ frequency of occurrence. The results of the distribution of fungal species on the experimental soil samples and their frequencies of occurrence are presented in Tables 1and 2. It was observed that these nondermatophyte keratinophiles and the T. mentagrophytes (dermatophyte) colonized the baited hairs and predominated right from the early stages of isolation. It could be possible that these highly competitive, fast growing groups of fungi having the ability to utilize less complex nutrient substrates colonized the keratin thereby suppressing the growth of the real keratinolytic fungi (24). In addition, it could also be possible that the individuals patronizing the barbers' shops are mostly not infected by the dermatophytes as people in townships are becoming aware of dangers of these pathogenic dermatophytic fungi and try to keep their bodies clean. Most of the experimental soil samples were sandy in nature and sandy soils are poorly inhabited by keratinolytic fungi as reported by Gugnani et al. (25). The results also agree with that of Ganaie, et al. (26) who reported least number of keratinolytic fungi (21\%) from sandy soils of rivers.

The dermatophyte species isolated in this study is a known anthropophilic species and is widely distributed in soil globally (Table 1). This species has previously been isolated from different soils throughout the globe and there are reports of its medical importance $(27,28,12)$.

The other non-dermatophyte species isolated from this study have also been reported in different areas of the world $(29,30$ and 31) as well as Nigeria $(32,11,33$ and 34) and are known as inhabitants of different soils. A. niger and $T$. viride were the most abundant and then followed by $A$. fumigatus and $P$. sp. In similar investigations, (35 and 36) also encountered the genera of Aspergillus as the most abundant. Isolation of 
Aspergillus species in this study is of medical importance as the group are associated with the disease known as Aspergillosis that are implicated in persons with compromised immunity. A. fumigatus is a known species for aflatoxin production which also is associated with liver cirrhosis. The Candida albicans isolated from this study is also of medical importance as it has been known to be the causative agent of candidiosis in females and they are also responsible for a lot of ocular infections in patients whose immune status has been compromised by surgery, trauma and age (34).

\subsection{Biochemical Tests}

The fungal isolates including both the dermatophyte and non-dermatophytes were capable of hydrolyzing starch and milk casein enzymatically indicating that they require glucose for their growth. The rate of starch, urea and protease hydrolysis differed with each species. The In vitro hair test was conducted for $T$. mentagrophytes alone and it was positive. The results of the biochemical tests on the fungal isolates are presented in Table 3.

\subsection{Thermotolerance studies}

The results of the thermotolerance studies on the isolated fungi indicate that there were mesophilic, thermotolerant and thermophilic species among them (Table 4). The isolates grew well at $25^{\circ} \mathrm{C}$ and shows that they are mainly mesophilic in nature. Candida albicans, which is the only pathogenic yeast isolated was a thermotolerant species as it grew better at $37^{\circ} \mathrm{C}$. The temperature of $45^{\circ} \mathrm{C}$ supported the growth of $A$. fumigatus, indicating that the species is thermotolerant in nature. The same incubation temperature also slightly supported the growth of A. niger, and this could be as a result of the dark colour of the species conidia which help them in retaining heat. This showed that the species are both thermophilic and thermotolerant in nature. The results of the thermotolerance studies on the isolates are presented in Table 4.

\subsection{Antimicrobial sensitivity screening}

The inhibitory activity of both the aqueous and ethanolic extracts of ginger rhizomes are shown in Tables 5 and 6 respectively. The aqueous extract was found to have potent antimicrobial activity against the test organisms than the ethanolic extract. It was found that the aqueous extract showed maximum antifungal activity against Curvularia lunata, Penicillium sp and Candida albicans, and antibacterial activity against Bacillus sp, Citrobacter sp and Staphylococcus aureus. There was no significant difference on the effect of the extract on $A$. niger and Fusarium solani.(Table 5). However, the different concentrations (500-31.25mg/ml) had significant effect on the test organisms inhibited.

For the ethanolic extract, there was no significant difference on the effect of the extract on $A$. niger, Fusarium sp, Candida albicans and Citrobacter sp. The concentration $500 \mathrm{mg} / \mathrm{ml}$ had significant effect on Bacillus sp, Curvularia lunata and Staphylococcus aureus but the effect on C. lunata and S. aureus are not significantly different from the other (Table 6). Zingiber officinale rhizomes have been used for decades in treatment of different ailments, and this is attributable to the active components of ginger. The components include citronellal, zingiberenol, terpenolene, ar-curcumene among others essential oils, alkaloids, flavones, coumarins and terpenoids. The mechanisms thought to be responsible for these phytochemicals against microorganisms vary and depend on these compounds (37). Their mechanism of actions may include enzyme inhibition by the oxidized compounds, and act as a source of stable free radical and often leading to inactivation of the protein and loss of function. They have the ability to complex with extracellular and soluble proteins, to complex with bacterial cell walls and disrupt microbial membranes; some have ability to intercalate with DNA, competitive inhibition of adhesion of microbial proteins to host polysaccharide receptors (38). The details of the antimicrobial sensitivity screening are presented in Tables 5 and 6. 
Table 1: Fungal Species Isolated From Experimental Soil Samples

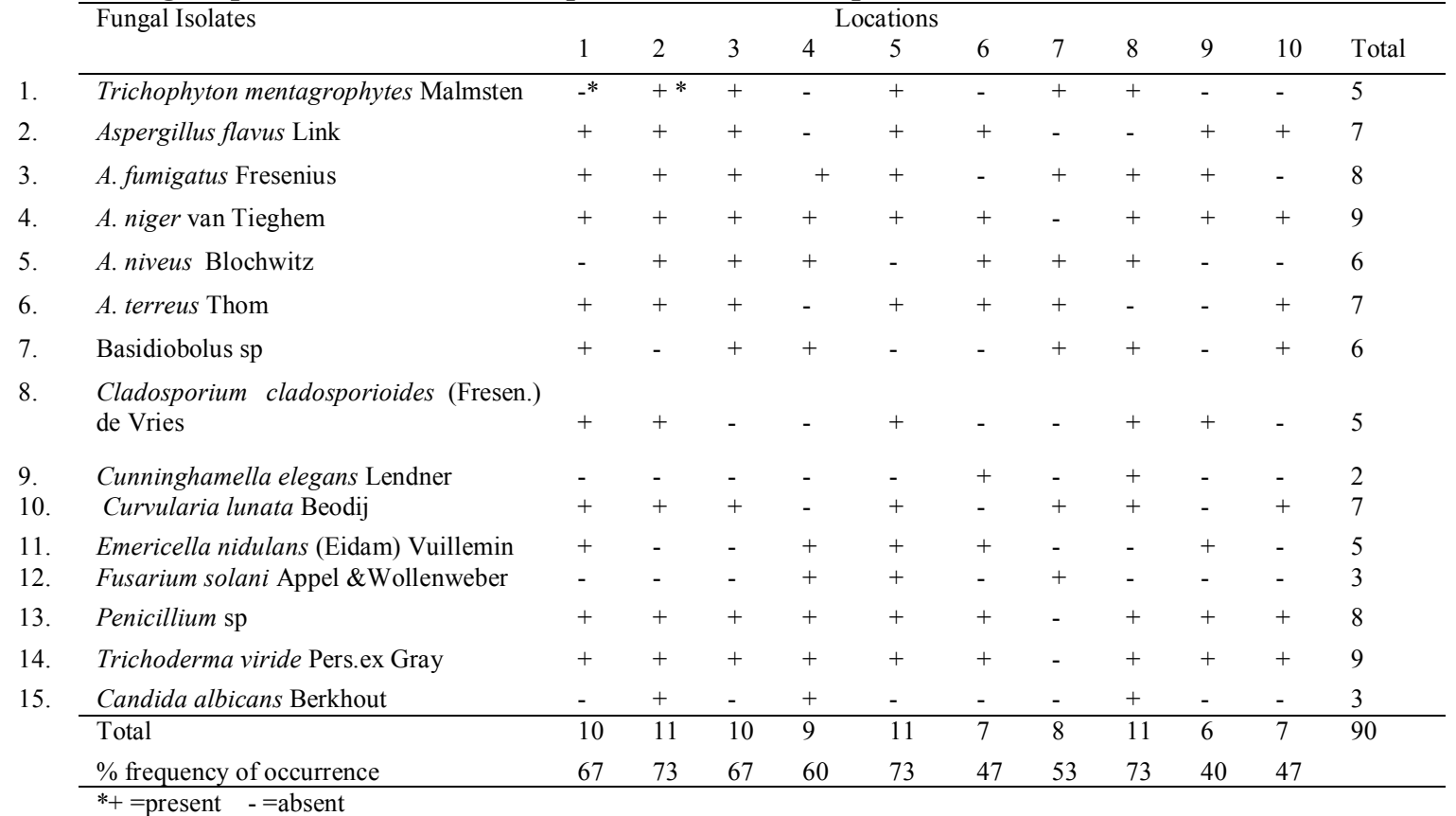

Table 2: Percentage Frequency Of The Fungal Isolates

\begin{tabular}{llccc}
\hline S/No & Fungal isolates & No of soil samples processed & No of positive species & \%value \\
\hline 1 & Trichophyton mentagrophytes & 30 & 12 & 40 \\
2 & Aspergillus flavus & 30 & 25 & 83 \\
3 & A.fumigatus & 30 & 27 & 90 \\
4 & A. niger & 30 & 30 & 100 \\
5 & A. niveus & 30 & 20 & 67 \\
6 & A.terreus & 30 & 25 & 83 \\
7 & Basidiobolus sp & 30 & 5 & 17 \\
8 & Cladosporium cladosporioides & 30 & 26 & 23 \\
9 & Cunninghamella sp & 30 & 7 & 100 \\
10 & Curvularia lunata & 30 & 24 & 27 \\
11 & Emericella nidulans & 30 & 20 & 67 \\
12 & Fusarium solani & 30 & 27 & 83 \\
13 & Penicillium sp & 30 & 28 & 93 \\
14 & Trichoderma viride & 30 & 24 & 80 \\
15 & Candida albicans & 30 & & \\
\hline
\end{tabular}

Table 3: Biochemical Tests On The Fungal Isolates

\begin{tabular}{|c|c|c|c|c|c|}
\hline S/No & Fungal Isolates & Starch Hydrolysis & Urease & Invitro hair & Protease \\
\hline 1. & Trichophyton mentagrophytes & + & +++ & $*+++$ & ++ \\
\hline 2. & Aspergillus flavus & + & ++ & $* \mathrm{ND}$ & ++ \\
\hline 3. & A. fumigatus & ++ & ++ & ND & ++ \\
\hline 4. & A. niger (series) & ++ & ++ & ND & ++ \\
\hline 5. & A. niveus & ++ & - & ND & ++ \\
\hline 6. & A. terreus & ++ & - & ND & ++ \\
\hline 7. & Basidiobolus sp & - & + & ND & - \\
\hline 8. & Cladosporium cladosporioides & ++ & + & ND & +++ \\
\hline 9. & Cunninghamella sp & - & - & ND & - \\
\hline 10. & Curvularia lunata & + & ++ & ND & ++ \\
\hline 11. & Emericella nidulans & ++ & - & ND & ++ \\
\hline 12. & Fusarium solani & + & + & ND & ++ \\
\hline 13. & Penicillium $s p$ & ++ & - & ND & ++ \\
\hline 14. & Trichoderma viride & +++ & - & ND & ++ \\
\hline 15. & Candida albicans & + & ++ & ND & ++ \\
\hline
\end{tabular}

*+ =positive

$\mathrm{ND}=$ Not Determined 
Table 4: Thermotolerance Studies On The Fungal Isolates From Experimental Soil Samples S/No $\quad$ Fungal Isolates Temperature $\left({ }^{\circ} \mathrm{C}\right)$

\begin{tabular}{lllll} 
& & 25 & 37 & 45 \\
\hline 1 & Trichophyton mentagrophytes & $+++* *$ & + & $-* *$ \\
2 & Aspergillus flavus & +++ & + & - \\
3 & A.fumigatus & ++ & +++ & +++ \\
4 & A. niger (series) & +++ & ++ & + \\
5 & A. niveus & +++ & - & - \\
6 & A. terreus & +++ & ++ & - \\
7 & Basidiobolus sp & +++ & + & - \\
8 & Clasdosporium clasdosporioides & +++ & - & - \\
9 & Cuninghamella sp & +++ & - & - \\
10 & Curvularia lunata & +++ & + & - \\
11 & Emericella nidulans & +++ & ++ & + \\
12 & Fusarium solani & +++ & + & - \\
13 & Penicillium sp & +++ & ++ & - \\
14 & Trichoderma viride & +++ & ++ & - \\
15 & Candida albicans & ++ & +++ & -
\end{tabular}

$* *+=$ present $-=$ absent

Table 5: Mean Effect Of Aqueous Extract Of Ginger On Test Organisms

\begin{tabular}{|c|c|c|c|c|c|c|c|}
\hline \multirow[b]{2}{*}{ Test Organisms } & \multicolumn{7}{|c|}{ Inhibition Zones Diameter (mm) } \\
\hline & $\begin{array}{c}500 \\
\mathrm{mg} / \mathrm{ml}\end{array}$ & $\begin{array}{c}250 \\
\mathrm{mg} / \mathrm{ml}\end{array}$ & $\begin{array}{c}125 \\
\mathrm{mg} / \mathrm{ml}\end{array}$ & $\begin{array}{c}62.5 \\
\mathrm{mg} / \mathrm{ml}\end{array}$ & $\begin{array}{l}31.25 \\
\mathrm{mg} / \mathrm{ml}\end{array}$ & $\begin{array}{c}\text { Control } \\
\text { (Nystatin) }\end{array}$ & $\begin{array}{c}\text { Control } \\
\text { (Gentamycin) }\end{array}$ \\
\hline \multicolumn{8}{|l|}{ Fungi } \\
\hline Aspergillus flavus & $0.00^{\mathrm{f}}$ & $0.00^{\mathrm{f}}$ & $0.00^{\mathrm{d}}$ & $0.00^{\mathrm{d}}$ & $0.00^{d}$ & $0.00^{\mathrm{d}}$ & - \\
\hline Curvularia lunata & $41.33^{\mathrm{a}}$ & $44.67^{\mathrm{a}}$ & $32.67^{\mathrm{a}}$ & $31.00^{\mathrm{a}}$ & $27.33^{\mathrm{a}}$ & $19.67^{\mathrm{a}}$ & - \\
\hline Fusarium solani & $0.00^{\mathrm{f}}$ & $0.00^{\mathrm{f}}$ & $0.00^{\mathrm{d}}$ & $0.00^{\mathrm{d}}$ & $0.00^{\mathrm{d}}$ & $0.00^{\mathrm{d}}$ & - \\
\hline Penicillium sp & $0.00^{\mathrm{f}}$ & $0.00^{\mathbf{b}}$ & $26.67^{b}$ & $21.00^{\mathbf{b}}$ & $16.00^{\mathrm{b}}$ & $16.67^{\mathrm{d}}$ & - \\
\hline Candida albicans & $33.33^{\mathrm{d}}$ & $18.00^{\mathrm{d}}$ & $15.67^{\mathfrak{c}}$ & $12.67^{\mathrm{c}}$ & $10.67^{d}$ & $0.00^{\mathrm{c}}$ & - \\
\hline \multicolumn{8}{|l|}{ Bacteria } \\
\hline Bacillus sp & $37.67^{\mathrm{b}}$ & $37.67^{\mathfrak{c}}$ & $18.33^{\mathrm{c}}$ & $11.67^{\mathfrak{c}}$ & $10.33^{\mathbf{c}}$ & - & $8.67^{\mathbf{b}}$ \\
\hline Citrobacter sp & $38.00^{\mathrm{e}}$ & $14.00^{\mathrm{e}}$ & $12.67^{\mathrm{d}}$ & $0.00^{\mathrm{d}}$ & $0.00^{\mathrm{d}}$ & - & $0.00^{\mathrm{b}}$ \\
\hline Staphylococcus aureus & $39.00^{\mathbf{c}}$ & $34.33^{\mathrm{a}}$ & $33.33^{\mathbf{b}}$ & $20.33^{\mathbf{b}}$ & $16.00^{d}$ & - & $0.00^{\mathbf{b}}$ \\
\hline $\mathrm{SE} \pm$ & 0.65 & 0.65 & 0.68 & 0.54 & 1.19 & 0.41 & 0.41 \\
\hline Remark & $\mathbf{s}$ & $\mathbf{s}$ & $\mathbf{s}$ & $\mathbf{s}$ & $\mathbf{s}$ & $\mathbf{s}$ & $\mathbf{s}$ \\
\hline
\end{tabular}

Means in the same column having the same superscript are not significantly different $(\mathrm{p}>0.05)$ $\mathrm{s}-$ significant

Table 6: Mean Effect Of Ethanolic Extract Of Ginger On Test Organisms

\begin{tabular}{|c|c|c|c|c|c|c|c|}
\hline \multirow[b]{2}{*}{ Test Organisms } & \multicolumn{7}{|c|}{ Inhibition Zones Diameter (mm) } \\
\hline & $\begin{array}{c}500 \\
\mathrm{mg} / \mathrm{ml} \\
\end{array}$ & $\begin{array}{c}250 \\
\mathrm{mg} / \mathrm{ml}\end{array}$ & $\begin{array}{c}125 \\
\mathrm{mg} / \mathrm{ml}\end{array}$ & $\begin{array}{c}62.5 \\
\mathrm{mg} / \mathrm{ml}\end{array}$ & $\begin{array}{c}31.25 \\
\mathrm{mg} / \mathrm{ml}\end{array}$ & $\begin{array}{c}\text { Control } \\
\text { (Nystatin) }\end{array}$ & $\begin{array}{c}\text { Control } \\
\text { (Gentamycin) }\end{array}$ \\
\hline \multicolumn{8}{|l|}{ Fungi } \\
\hline Aspergillus flavus & $0.00^{\mathrm{c}}$ & $0.00^{\mathrm{c}}$ & $0.00^{\mathbf{c}}$ & $0.00^{\mathbf{c}}$ & $0.00^{\mathrm{d}}$ & $0.00^{\mathrm{d}}$ & - \\
\hline Curvularia lunata & $16.67^{\mathrm{a}}$ & $20.33^{\mathrm{a}}$ & $22.33^{\mathrm{b}}$ & $23.67^{\mathbf{b}}$ & $26.67^{\mathrm{c}}$ & $41.33^{\mathrm{a}}$ & - \\
\hline Fusarium solani & $0.00^{\mathbf{c}}$ & $0.00^{\mathrm{c}}$ & $0.00^{\mathrm{c}}$ & $0.00^{\mathrm{c}}$ & $0.00^{\mathrm{d}}$ & $0.00^{\mathrm{d}}$ & - \\
\hline Penicillium sp & $0.00^{\mathrm{c}}$ & $0.00^{\mathrm{c}}$ & $0.00^{\mathrm{c}}$ & $0.00^{\mathrm{c}}$ & $0.00^{\mathrm{d}}$ & $0.00^{\mathrm{d}}$ & - \\
\hline Candida albicans & $0.00^{\mathrm{c}}$ & $0.00^{\mathrm{c}}$ & $0.00^{\mathrm{c}}$ & $0.00^{\mathrm{c}}$ & $0.00^{\mathrm{d}}$ & $33.33^{\mathrm{c}}$ & - \\
\hline \multicolumn{8}{|l|}{ Bacteria } \\
\hline Bacillus sp & $12.00^{\mathrm{b}}$ & $14.67^{\mathrm{b}}$ & $21.67^{\mathbf{b}}$ & $25.33^{\mathrm{b}}$ & $28.33^{\mathbf{b}}$ & - & $37.67^{\mathbf{b}}$ \\
\hline Citrobacter sp & $0.00^{\mathrm{c}}$ & $0.00^{\mathrm{c}}$ & $0.00^{\mathrm{c}}$ & $0.00^{\mathbf{c}}$ & $0.00^{\mathrm{d}}$ & - & $38.00^{\mathbf{b}}$ \\
\hline Staphylococcus aureus & $15.67^{\mathrm{a}}$ & $21.00^{\mathrm{a}}$ & $25.33^{\mathrm{a}}$ & $27.67^{\mathrm{a}}$ & $33.67^{\mathrm{a}}$ & - & $39.00^{\mathbf{b}}$ \\
\hline $\mathrm{SE} \pm$ & 0.49 & 0.26 & 0.46 & 0.58 & 0.41 & 0.65 & 0.65 \\
\hline Remarks & $\mathbf{s}$ & $\mathbf{s}$ & $\mathbf{s}$ & $\mathbf{s}$ & $\mathbf{s}$ & $\mathbf{s}$ & $\mathbf{s}$ \\
\hline
\end{tabular}

Means in the same column having the same superscript are not significantly different $(\mathrm{p}>0.05)$ $\mathrm{s}-$ significant 


\section{Conclusion}

The inhibitory effect of Zingiber officinale (ginger) used as food additive should be of importance in medicine. Ginger has great potentials for the development of antimicrobial drugs most especially for the treatment bacterial wound infections Candidiosis caused by Candida albicans and opportunistic infections caused by fungi such as Curvularia lunata.

\section{Acknowledgement}

The authors are grateful to Department of Basic Science and General Studies, Federal College of Forestry Jos, Nigeria for providing us with the Laboratory space and some of the facilities used for carrying out the study.

\section{References}

[1]. Gugnani, H.C. Non-dermatophytic filamentous keratinophilic fungi and their role in human infections in R. K. S. Kushwaha, and J. Guarro, (Eds). Biology of Dermatophytes and other Keratinophilic Fungi. (Spain: Revista Iberoamericana de Micologia Apartado, Bilbao, 2000), 109-114.

[2]. Hedayati, M.T., A. Mohseni-Bandpi, S. Moradi, A survey on the pathogenic fungi in soil samples of potted plants from Sari hospitals, Iran. Journal of Hospital Infection, 2004, 58: 59-62.

[3]. Onifade, A.A., N. A. Al-Sane, A. A. Al-Musallam, and S. Al-Zarban, Potentials for biotechnological applications of keratin degrading microorganisms and their enzymes for nutritional improvement of feathers and other keratins as livestock feed resources. Bioresource Technology, 1998, 66, 1-11.

[4]. Hainer, B.L.and Dermatophyte, Infections, American Family Physician, 2003, 1: 101-108.

[5]. Mohamed, S., Ali-Shtayeh, S.M. and M.F.J. Rana, Keratinophilic fungi and related dermatophytes in polluted soil and water habitats, in R. K. S. Kushawaha, and J. Guarro (Eds.), Biology of dermatophytes and other keratinophilic fungi , (Spain: Revista Iberoamericana de Micologia Apartado, Bilbao, 2000) 51-59.

[6]. Mercantini, R., R. Marsella, F. Caprilli, and G. Dovgiallo, Isolation of dermatophytes and correlated species from the soil of public gardens and parks in Rome. Sabouraudia, 1980, 18: 123-128.

[7]. Ramesh V.M. and A. Hilda, Incidence of keratinophilic fungi in the soil of primary schools and public parks of Madras City, India. Mycopathologia, 1998; 143: 139-145.

[8]. Deshmukh, S.K. Incidence of keratinophilic fungi from selected soils of Kerala state (India). Mycopathologia, 2002 , 156 : $177-181$.

[9]. Ogbonna, C.I.C., R.O. Robinson, and J. M. Abubakar, The distribution of ringworm infections among primary school children in Jos, Plateau State. Mycopathologia , 1985, 59: 101-106.

[10]. Ogbonna, C.I.C., I. E. Enweani, and S. C. Ogueri,. Seasonal variations in the occurrence of ringworm infections amongst Nomadic Fulani Herdsmen. Inter Journ. of Nomadic and Minority Education, 1987, 1 (2): 33-38.

[11]. Nwadiaro, P.O. Incidence of Dermatophyte Infections amongst some occupational and select groups in Jos. Afr. J. Clin. Exp. microbiol. 2003, 4: (2) 11-17.

[12]. Gupta, S., A. Mishra, and A. K. Gupta, Isolation and Identification of Keratinophilic Fungi from Soil of Gwalior Region and their Control by Methanolic Plant Extracts. Journ. of Biomedical and Pharm. Res., 2012, 1(3): 1-21.

[13]. Hoog, S. Effect of natural antifungals on keratinophilic fungi isolated from soil. Mycoses. 1996, 39: 407-417.

[14]. Bhargava, S., K. Dhabhai, A. Batra, A. Sharma, and B. Malhotra, Zingiber Officinale : Chemical and phytochemical screening and evaluation of its antimicrobial activities. J. Chem. Pharm. Res., 2012, 4(1): 360-364.

[15]. Vanbreuseghem, R.Technique biologique pour I' isolement des dermatophytes du sol. Ann Soc Beige Med Trop., 1952, 32: 173178 .

[16]. Domsch, K.H and W. Gams, Fungi in Agricultural Soils. (Edinburgh, Longman Group Ltd, 1972).

[17]. Von Arx, J.A. The Genera of Fungi Sporulating in Pure Culture (Germany J. Cramer 1974).

[18]. Barron, G.L. The Genera of Hyphomycetes from Soil (New York: Robert E. Krieger Publishing Company 1977).

[19]. Raper K.B. and Fennell, D. I. (1977). The Genus Aspergillus (Huntington New York: Robert E, Krieger Publishing Company.

[20]. Samson, R.A., E. S., Hoekstra, C. A. N. Van Ooschot, and L. R. De Miranda, Introduction to Food-Borne Fungi (Netherlands: Centraalbureau voor Schimmelcultures, Baarn, 1984).

[21]. De Hoog, J. S., Guarro, J. Gené, J. Figueras, M. J. Atlas of clinical Fungi 2. (Vyd. Utrecht: Centraalbureau Voor Schimmelcultures, 2000).

[22]. Staba, E.J., L. Lisal, and J. E. Staba, A commentary on the effects of Garlic Extraction and formulation on product composition. J. Nutr. 2001, 131: 11185-11195.

[23]. Tortora, G.J., B. R. Funke, and C. L. Case, Microbiology, An Introduction.7th Edn. World Health Organisation's General Guidelines for Methodologies on Research and Evaluation of Traditional Medicine, (WHO, Geneva, Switzerland, 2005.)

[24]. Simpanya, M.F and M. Baxter, Isolation of soil fungi using the keratin-baiting technique. Mycopathologia, 1966, 136: 85-89.

[25]. Gugnani, H.C., S. Sharma, B. Gupta, and S. Gaddam, Prevalence of keratinophilic fungi in soils of St. Kitts and Nevis. J Infect DevCtries 2012, 6 (4):347-351.

[26]. Ganaie, M.A., S. Sood, G. Rizvi, and T. A. Khan, Isolation and Identification of Keratinophilic Fungi from Different Soil Samples in Jhansi City (India). Plant Pathology Journal, 2010, 9: 194-197.

[27]. Sarquis, M.I.M., P. C. Oliveira, Diversity of microfungi in the sandy soil of Ipanema Beach, Rio de Janeiro, Brazil, J Basic Microbiol, 1990, 36: 51-8.

[28]. Ali, Z.M. and Z. Majid, Isolation of dermatophytes and related keratinophilic fungi from the two public parks in Ahvaz Jundishapur, Journal of Microbiology 2008, 1(1): 20-23.

[29]. Asan, A Checklist of Aspergillus and Penicillium species reported from Turkey. Turk. J. Bot., 2000, 24: 151-167.

[30]. Spiewak, R. and R. Szostak, Zoophilic and geophilic dermatophytes among farmers and non- farmers in eastern Poland. Ann. Agr. Environ. Med., 2000, 7: 125-29.

[31]. Panda, T. P. K., Pani, N. Mishra, and R. B. Mohanty, A comparative account of the diversity and distribution of fungi in tropical forest soils and sand dunes of Orissa, Indian, Journal of Biodiversity, 2010, 1(1): 27-41.

[32]. Ogbonna, C.I.C and G. J. F. Pugh, Nigerian Soil Fungi Nova Hedwegia 1982, 36, 795-808

[33]. Durowade, K.A., O. M. Kolawole, R. O. Uddin ii, and K.I. Enonbun, Isolation of Ascomycetous Fungi from a Tertiary Institution Campus Soil. J. Appl. Sci. Environ. Manage. 2008, 12 (4), 57 - 61. 
[34]. Ewekeye, T. O. Oke, and M. Li-Hammed, Soil mycoflora studies of some locations in Lagos State, Nigeria. Rep Opinion, 2012, 4 (4), 52-57.

[35]. Maren, K.A. Biogeography of Aspergillus species in soil and litter. Mycologia 2002, 94 (1), $21-27$.

[36]. Suhail, M., I. Fozia, T. Jatt, K. Farzana, and H. Abro, Aspergillus mycoflora isolated from soil of Kotri Barrage Sindhi, Pakistan. Pakistan Journal of Botany 2007, 39 (3), 981-984.

[37]. Amer, S., M. M. Aly, S. Sabbagh, Biocontrol of dermatophytes using some plant extracts and actinomycetes filtrates. Egyptian J. Biotechnol., 2006, 14: 291-315.

[38]. Cowan, M.M. Plant products as antimicrobial agents. Clin. Microbiol. Rev., 1999, 12: 564-582 